\title{
DOES SOCIAL CAPITAL INFLUENCE DEBT LITERACY? \\ THE CASE OF FACEBOOK USERS IN POLAND
}

\section{Kamil Filipek, Andrzej Cwynar, Wiktor Cwynar*}

\begin{abstract}
Debt literacy has been considered to be a critical competence of modern societies since the recent global financial crisis. Debt-literate individuals are less prone to financial abuse and perform better in terms of credit management. Currently, debt-related information and knowledge are widely accessible through social networking sites (SNS), such as Facebook. However, not all SNS users have equal access to debt-related resources, and, consequently, they reach different scores in debt literacy tests. This study examines relational factors (resources) behind the debt literacy of Facebook users $(\mathrm{N}=1,055)$ in Poland by applying the Resource Generator tool built into the online questionnaire. This quantitative instrument helps to diagnose resources that are embedded and mobilised (social capital) from personal networks made up of kin, friends and acquaintances. We found that users with more social capital, that is, better access to resources, perform better in debt literacy tests. Moreover, weak ties (acquaintances) appear to be good sources of debt-related information and knowledge that have positive impact on debt literacy scores.
\end{abstract}

Keywords: social capital, debt literacy, financial literacy, Facebook, social media JEL Classification: D83, G41, L82

\section{Introduction}

The rapid increase in volume and complexity of financial products aimed at individual customers has been found as one of many factors behind recent global economic crises (Crotty, 2009). Financial institutions developed their unique offers in order to attract customers and, consequently, to outperform competitors with little awareness of potential socio-economic consequences. Mortgage-backed securities (MBS), asset-backed securities (ABS), collateralised mortgage obligations (CMO) or collateralised debt obligations (CDO) are examples of complex products available to ordinary customers that contributed to the global financial tornado of 2008. Unfortunately, some recent data suggest that many people have recovered from the recent global crisis and they again seek new forms of borrowing (FED NY, 2017).

* Kamil Filipek, Maria Curie-Skłodowska University (UMCS), Lublin, Poland (kfilipek@umcs.pl);

Andrzej Cwynar, University of Economics and Innovation (WSEI), Lublin, Poland

(andrzej.cwynar@wsei.lublin.pl);

Wiktor Cwynar, University of Economics and Innovation (WSEI), Lublin, Poland

(wiktor.cwynar@wsei.lublin.pl).

Kamil Filipek thanks the National Science Centre (NCN, Poland) for support through Grant no. 2014/12/S/HS6/00390. Andrzej Cwynar and Wiktor Cwynar thank the Ministry of Science and Higher Education for support through Grant 'Debt Watch', no. 0057/DLG/2016/10 under the programme 'Dialogue'. 
However, credits are not equally available on the market and many customers are more or less excluded from borrowing under fair conditions. For example, poorer people are often forced to turn to high-cost sources of credit such as payday loans or payroll loans, usually offered by non-bank financial intermediaries. Particularly, those in the lowest income brackets and lower levels of education are frequent victims of the predatory rent-to-own system depriving of ownership until the final instalment (Crossney, 2017). Despite the devastating consequences of the global financial crisis, many countries have not improved their financial regulations enough in order to protect their poorest and most vulnerable citizens. This may suggest that state interventions do not keep up with the dynamics (innovation) of financial markets, and, consequently, institutional protection fails to protect borrowers with feeble credit scores.

Building on that, it is proposed that access to financial knowledge and information contributes to debt literacy of financial market participants and helps them to avoid debtrelated risks and problems. In the age of social media, access to diverse resources that may boost debt literacy has become faster, easier and wider (Ellison et al., 2014; Lampe et al., 2012; PEW, 2015). For example, Facebook equips its users with a range of tools such as groups, notifications or following that enable pulling both in and out of diverse material or symbolic resources (Baborska-Narozny et al., 2016; Hamidi and Baljko, 2010). Consequently, Facebook may serve as a modern learning environment (Mazer et al., 2007) with peer-assessed information (Facebook "likes") that contributes to the debt literacy of its users. However, access to and mobilisation of resources from Facebook depends on quantity and quality of peers added to one's network, as well as individual patterns of Facebook use (Wells and Link, 2014). It is rather unusual to have many Facebook "friends" with profound knowledge of credit products, financial law, and so forth. Thus, improvement in debt literacy through Facebook is appealing, but it is a rather complex process with many unanswered questions and emerging dilemmas.

Debt literacy has been measured in Poland previously, including the channels through which consumers acquire the literacy. Cwynar et al. (2018) surveyed a representative sample of adult Poles $(\mathrm{N}=1,004)$ with a twelve-question 'true/false' test probing their debt literacy on a scale from -12 to 12 . The mean test score in the total sample reached -1.22 , meaning that the average grown-up Pole is actually debt-illiterate. The study found that the source of debt knowledge and skills most often used is the Internet (indicated by $32 \%$ of the respondents), followed by friends and colleagues (13.3\%), books and professional press (13.3\%), and family (12.5\%). Białowolski et al. (2019) received similar results regarding the levels of debt literacy, although with different instruments (nationally representative sample of adult Poles, $\mathrm{N}=1,004)$ : the mean debt knowledge and debt skill test scores were 6.62 (on a scale from 0 to 12) and 1.68 (on a scale from 0 to 5), respectively. The study also showed that the effectiveness of the economic education - including its impact on debt literacy - may be related to the teacher's gender. This research evidenced that both the debt knowledge and debt skills were significantly and positively related to being taught economics by a male teacher in the childhood. More general (i.e., more diversified in terms of themes and financial domains) financial literacy tests conducted in recent years in Poland have shown 
similar results. They document that the level of financial literacy in the Polish population is generally low, yet diversified in sociodemographic and economic cross-sections (see, for instance, Instytut Wolności and Raiffeisen Polbank, 2014; OECD INFE, 2016).

This study examines relational factors behind debt literacy of Facebook users in Poland. In doing so, Nan's theory of social resources (Lin, 1999, 2001) is applied to understand mechanisms shaping availability and mobilisation of resources embedded in personal networks that may have an impact on debt literacy. Despite the enormous influence of financial literacy - not only on households' economic well-being, but also on social status - research into financial literacy has been neglected by sociologists, and left mostly to economists. We placed the matter of financial literacy in a more sociological framework, and applied a more interdisciplinary approach to examining and discussing it. Moreover, we focused our attention on a little-studied aspect of financial literacy - i.e., debt literacy because debt-related problems, presumably arising (at least partly) as a consequence of debt literacy shortcomings, have proven to effectively unite individuals into organised groups (e.g., Swiss franc mortgage holders - so called "Frankowicze" - in Poland; see Buckley, 2016). As a consequence, we pursue the following research questions: (i) Do resources embedded in personal networks of Facebook users have an impact on their debt literacy scores? (ii) Whose resources (family, friends, acquaintances) have an impact on debt literacy of Polish Facebook users? (iii) Do individual predispositions (personal resources) influence debt literacy?

The reminder of the paper is organised as follows. In Section 2 we make a literature review with special attention paid to issues related to the interlinks among social capital, financial education and financial literacy. Section 3 is the methodological part, in which we demonstrate the research tools, data and models used in the study. The empirical results and discussion of them are demonstrated in Section 4. The last section concludes the paper.

\section{Theoretical Background}

\subsection{Social capital, education and literacy}

Although there is no explicit economic theory of social capital, the problems associated with it have received noticeable attention among economists worldwide (Collier, 2002; Dasgupta, 2005; Ostrom, 1995). It has been established that social capital may lead to a range of positive effects such as a higher level of innovation (Patton and Kenney, 2003), better labour market position (Batorski et al., 2015; Granovetter, 1974), higher occupational status attainment (De Graaf and Flap, 1988), greater engagement in politics (La Due Lake and Huckfeldt, 1998) or stronger ties with the neighbourhood (Hays, 2015). Individuals with better access to social capital have greater chances to achieve diverse goals at school, in the workplace, family or local community.

Accordingly, it has also been found that social capital affects an individual's educational achievements at different stages of personal development (Rogosic and Baranovic, 2016). Coleman (1988) suggested that educational results depend on cohesion of communities in which individuals are embedded. Communities with higher levels of closure between 
members are more effective in production and distribution of norms regulating reciprocal actions. For Coleman, therefore, social capital is a structural property determining children's educational results. In a similar vein, Putnam (2000) found that social capital has a significant effect on children's educational outcomes. He claims that "Socioeconomic and demographic characteristics do matter - but so does social capital" (ibid, p. 297). Particularly good predictors of educational achievements are (i) engagement in peer social networks and (ii) extracurricular activities. Thus, it is evident that social capital matters when an individual's educational achievements, skills and knowledge are evaluated.

Following on from that, Falk (2001) examined the relationship between social capital and literacy of members of the Community Education Centre in Australia. He found that networks, shared values and trust are important factors having an impact on the literacy learning process. In this view, literacy is gained through interactive processes in which social capital mobilises resources necessary for learning. Falk (2001) identified that a combination of trust, strong (bonding) ties and weak (bridging) links has an impact on the literacy learning process. In other words, the network structure of connections provides the basis for different forms of learning and knowledge distribution. The positive role of connections in lifelong learning has been further confirmed by Field (2005), who describes social ties as a form of social capital that may be transformed for different educational outcomes. In this view, people acquire knowledge and skills through connections with peers, relatives, friends or acquaintances. He also found that bonding social capital encourages participation in formal education and training while bridging social capital facilitates alternative (non-institutional) ways of gaining information, knowledge and skills. Similarly, Tett and Maclachlan (2007) identified the relationship between social capital and engagement in learning among adults in Scotland. They suggest that there is a two-way relationship ("virtuous circle") between social capital and learning. Depending on the learning phase, social capital may have an impact on learning or learning may enhance social capital.

Drawing from the research in this area, we assume that social capital may have an impact on debt literacy of social media users. Our sample appears to be particularly interesting as social media users have great opportunities to build personal networks of connections and access diverse resources (Filipek, 2016) stimulating learning through Facebook tools (e.g., Facebook groups). Both strong (family, friends) and weak ties (acquaintances) may encourage individuals to acquire debt-related information, knowledge and expertise (Valenzuela et al., 2017). For example, Facebook users may share comments on changes in financial regulatory settings, advice for over-indebted consumers or warnings about debt market products. It is therefore little surprising that social media and other internetbased technologies are a persistent part of daily life with the ability to shape online and offline interactions in various social domains (economics, politics, culture, etc.). Building on these arguments, we hypothesise that users with more social capital are more debtliterate as they have more opportunities to mobilise resources encouraging learning (H1). In other words, individuals with better access to diverse resources have more chances to improve their debt-related knowledge and skills, that is, are more debt-literate. 


\subsection{Social capital as a social resource}

Decades of research focused on different forms of capital have concluded that group or community-level conceptualisations of social capital are not robust and may lead to doubtful results. For example, Putnam's $(1995,2000)$ studies have been heavily criticised for the vague definition of social capital and, consequently, faulty methods chosen for data collections. Skocpol (1996), Paxton (1999), Wellman et al. (2001), Durlauf (2002) or Fischer (2005) point to (i) vague causal relationships between variables related to social capital, (ii) inaccuracy of quantitative indicators, (iii) low quality of data or (iv) latent assumptions behind operationalisations of examined phenomena. For all of these reasons, the research presented in this article applies Lin's theory of social resources, relying on individual approach to social capital.

Borrowing from earlier conceptualisations (Bourdieu, 1986; Coleman, 1988; De Graaf and Flap, 1988; Loury, 1977), Lin approaches social capital as an individual property derived from relations with others. Such an approach appears to be convergent with the microeconomic postulate to search for the measurable externalities arising from social interactions (Collier, 2002). In this view, connections with kin, friends, acquaintances, workmates or even strangers are a source of material and non-material resources that may have an impact on individual actions. "Actors (whether individual or corporate) are motivated by instrumental or expressive needs to engage other actors in order to access these other actors' resources for the purpose of gaining better outcomes." (Lin, 2001, p. xi) Thus, social capital is conceptualised here as a relational property enabling access to resources, such as trust, recommendation, information, knowledge or money that may have an impact on people's actions (purposive actions). Lin distinguishes two types of resources: (i) personal resources, which are possessed by the individual (education, knowledge, skills, etc.) and (ii) social resources, which are accessed through relations with others. In contemporary social science, personal resources are often conceptualised as human capital, while social resources are perceived as social capital. What appears to be important is that the diversity of resources that individuals may access and mobilise depends on quality and quantity of relations they have with others.

It has been further established that different types of relations enable (or disable) access and/or mobilisation of different types of resources possessed by others. In order to explain this dependency, Granovetter's (1973) hypothesis of the "strength of weak ties" appears to be particularly useful. The strength of a tie was measured here as "a combination of the amount of time, the emotional intensity, the intimacy, and the reciprocal services which characterise the tie" (Granovetter, 1979, p. 1361). Strong ties are traditionally referred to as relations with family members and friends, while weak ties characterise connections with acquaintances, or, in modern settings, with online peers. Granovetter (1974) found that structurally weak ties are effective sources of job-related information for individuals active on the labour market as they extend reach and speed up information flow. On the contrary, Krackhardt found that strong ties "are more likely to be useful to the individual when that individual is in an insecure position" (Krackhardt, 1992, p. 218). Steffes and Burgee (2009) confirmed Granovetter's hypothesis and showed that in an online communication environment, users 
often rate weak ties as a more valuable source of information than strong ties. Although Granovetter's hypothesis cannot be proven, sometimes it appears to be a useful framework for analysis of the relationship between social capital and debt literacy of social media users.

Social media and online communication tools have increased the size of the personal networks of individuals engaged in online and offline domains. As a consequence, users find new opportunities to reach material and symbolic resources through weak and strong ties with peers. Valenzuela et al. (2018) showed that Facebook users effectively exploit strong ties while Twitter users rely on weak ties when they mobilise resources necessary for political participatory activities. Bakshy et al. (2012) examined the patterns of information spread in social networks. Their experimental approach on Facebook confirmed that weak ties enable the diffusion of novel information while strong ties have a potential to influence individuals. Thus, in an online environment, weak ties act as bridges that connect users with no or few mutual contacts. These findings may suggest that learning on social media is considerably enhanced by weak ties as they increase users' ability to reach unique resources, such as debt-related information and knowledge. Drawing from the research in this area, we, therefore, hypothesise a positive impact of resources reached through weak ties (acquaintances) on debt literacy of Facebook users in Poland (H2). Consistently with Granovetter's hypothesis, it is assumed here that weak ties (both embedded and mobilisable) facilitate distribution of novel information, knowledge or skills, which may, in turn, increase debt literacy of social media users.

Previous research showed that resources may have different impact on respondents' actions depending on their factual or real availability (Batorski et al., 2015; Pena-López and Sánchez-Santos, 2017). People declare to have a range of resources present in their personal networks with limited possibility to use them for purposive actions. For example, we may have affluent but rather greedy friends unwilling to share their wealth. It means that capital made of resources belonging to those friends cannot be activated and used for different purposes (communal or private). In fact, goods they possess are present in our personal network but appear to be "frozen" - that is, temporarily or permanently unavailable. Thus, some resources may be embedded in personal networks, but there is no or limited chance to mobilise them when they are needed by individuals. Consequently, the impact of such resources is problematic as respondents assume they cannot use them in different situations. Building on this framework, we therefore tested the following hypothesis: Users with better access to mobilisable resources achieve better results in debt literacy tests (H3).

\section{Methodology}

\subsection{Data and sampling}

We reached out to Facebook users between 28 May 2017 and 6 June 2017 through the online panel provided by Pollster Institute - a research company operating in Poland. As there is no complete list (sampling frame) of Polish Facebook users with debt experience, we decided to use a purposive sampling method to find respondents with particular characteristics. The aim was to carry out a heterogeneous sample in order to provide as much insight as 
possible into the studied phenomenon ${ }^{1}$. Thus, the online questionnaire (CAWI) was limited to Facebook users with current loan experience or those having debt in the last five years.

Table 1 | Sample Characteristics

\begin{tabular}{|c|c|c|c|c|c|c|}
\hline & \multicolumn{2}{|c|}{ Sample } & \multicolumn{2}{|c|}{ FB users - Poland ${ }^{1}$} & \multicolumn{2}{|c|}{ Total population - Poland ${ }^{2}$} \\
\hline & $\%$ & $\mathbf{N}$ & $\%$ & $N(m \mid n)$ & $\%$ & $N(m / n)$ \\
\hline \multicolumn{7}{|c|}{ Gender } \\
\hline Male & 48 & 511 & 49 & 9.9 & 48 & 18.6 \\
\hline Female & 52 & 544 & 51 & 10.2 & 52 & 19.8 \\
\hline All & 100 & 1,055 & 100 & 20.1 & 100 & 38.4 \\
\hline \multicolumn{7}{|c|}{ Place of residence } \\
\hline Village & 35 & 368 & 38 & 7.6 & 40 & 15.3 \\
\hline Town up to 20,000 & 9 & 98 & 13 & 2.6 & 13 & 5.0 \\
\hline City $20,001-50,000$ & 10 & 104 & 11 & 2.2 & 11 & 4.3 \\
\hline City 50,001-100,000 & 11 & 114 & 9 & 1.8 & 8 & 3.0 \\
\hline City $100,001-200,000$ & 8 & 88 & 8 & 1.6 & 8 & 3.2 \\
\hline City $200,001-500,000$ & 11 & 114 & 8 & 1.6 & \multirow{2}{*}{20} & \multirow{2}{*}{7.6} \\
\hline City 500,001 or more & 16 & 169 & 12 & 2.4 & & \\
\hline All & 100 & 1,055 & 99 & 20.1 & 100 & 38.4 \\
\hline \multicolumn{7}{|c|}{ Educational attainment } \\
\hline Primary school & 0.7 & 7 & 3 & 0.6 & 13 & 4.9 \\
\hline Junior high school & 0.7 & 7 & 4 & 0.8 & 5 & 1.5 \\
\hline Basic vocational school & 9 & 96 & 18 & 3.6 & 18 & 7.0 \\
\hline Secondary (uncompleted) & 3 & 33 & 7 & 1.4 & - & - \\
\hline Secondary & 28 & 292 & 26 & 5.2 & 28 & 10.7 \\
\hline Post-secondary school & 11 & 112 & 4 & 0.8 & - & - \\
\hline Bachelor's degree & 7 & 76 & 7 & 1.4 & - & - \\
\hline $\begin{array}{l}\text { Master's degree } \\
\text { (uncompleted) }\end{array}$ & 1 & 25 & 5 & 1.0 & - & - \\
\hline Master's degree & 38 & 399 & 18 & 3.6 & 23 & 8.8 \\
\hline PhD or higher & 0.8 & 8 & - & - & - & - \\
\hline All & 100 & 1,055 & $92^{*}$ & $18.5^{*}$ & $86^{* *}$ & $32.9 * *$ \\
\hline
\end{tabular}

Note: * Our sample contains users 18+, while Megapanel PBI/Gemius (2015) includes users 7+.

** Only citizens with completed primary school at least.

Source: 1 Megapanel PBI/Gemius (2015), internet users aged 7+.

2 Demographic Yearbook of Poland (2018), Statistics Poland, Warsaw.

1 There are more than 89,000 panellists enrolled on the platform from which we have recruited our respondents. Company we cooperate in this project adjust the structure of respondents in order to mirror the distributions of major demographic variables characterising Polish society (e.g., gender, age, place of residence, education). 
Due to dynamic changes on the credit market, we assumed that individuals with credit older than five years may not be aware of many details related to contemporary forms of borrowing. In total 1,055 respondents with debt experience as mentioned above were recruited to our study. Table 1 includes more characteristics of the sample compared to the Polish Facebook' population and the total population of Poland.

Although the purposive sampling method is very useful when the targeted sample is needed to be reached, there are some risks that need to be mentioned here. It is often raised that non-probable methods decrease the overall accuracy of samples (Yeager et al., 2011) and different panels may produce different results (Callegaro et al., 2014). However, this appears to be a wider problem of many quantitative methods used in contemporary social science that cannot be explicitly limited to panel research (Open Science Collaboration, 2015). At the same time, there are studies showing that non-probable online samples have levels of accuracy similar to probability-based online panels (Martinsson et al., 2013). Moreover, random samples (probability) often suffer from low recruitment rates and have problems with the completeness of the sampling frame (Rivers, 2007). In such cases, researchers often struggle to maintain the quality of probability sampling. Thus, the review of both approaches led Hays et al. (2015) to the conclusion that probability and non-probability sampling produce similar errors of estimates. However, the most obvious advantage of the purposive sampling is the final costs of the research.

\subsection{Measuring tool}

Researchers following the theory of social resources choose among three commonly used tools designed to measure social capital through resources embedded in personal networks: (i) a name generator, (ii) a position generator and (iii) a resource generator (Lin and Dumin, 1986; van der Gaag and Snijders, 2005; van der Gaag et al., 2008). This study uses the resource generator as it (i) fits CAWI research and smoothly complements the other parts of the questionnaires, (ii) allows one to examine different dimensions of social capital defined through resources, (iii) successfully passes a validation test that diminishes other quantitative tools measuring social capital (Appel et al., 2014).

Snijders and van der Gaag (2005) proposed the Resource Generator questionnaire made of items related to two dimensions of social capital. The first set of items ("Do you know anyone who ...") informs which resources a respondent knows are possessed by kin, friends and acquaintances. The second set ("Do you know anyone who can ...") reveals which resources can be mobilised for purposive actions (e.g., job search, voting, learning). A questionnaire based on these two blocks of questions allowed us to identify the gap between embedded resources and the ability to mobilise them through social ties. Items in the measuring tool should represent resources selected as relevant to the research problem (Ormel et al., 1997). In our questionnaire, we identified three resources of social capital with probable impact on debt literacy: (i) knowledge, (ii) recommendation, (iii) material goods. Consequently, nine items measuring embedded resources and nine items measuring mobilisable resources were included in the final version of the questionnaire used in our research. It means that each resource (embedded and mobilisable) is measured with three separate items in the final questionnaire. 


\subsection{Variables}

Our dependent variable - debt literacy - was measured by the instrument proposed by Lusardi and Tufano (2009). As a consequence, Facebook users were asked three questions measuring their knowledge and skills related to debt. Translation to Polish is fully consistent with the original questions included in the test proposed by Lusardi and Tufano (2009) $)^{2}$. In this research, debt literacy of Facebook users is set as a sum of answers given for all three questions borrowed from the mentioned test (from 0 to 3 ).

Our main independent variables are made of items included in the Resource Generator tool (see the Appendix). Social capital is measured here as: (i) aggregated property made of resources embedded in family, friends and acquaintances' circles, (ii) split attribute derived from resources identified in all three types of contacts. Both aggregated and split resources were measured as embedded and mobilisable attributes. In accordance with prior research (van der Gaag and Snijders, 2005), we constructed social capital scales using Mokken's (1971) scaling procedure to make sure that all items in our questionnaire measure the same latent concept. More details on how to build scales with automated selection algorithm can be found in Ark's seminal article (2007). Figure 1 presents distributions of scales and sub-scales derived from social capital items. Moreover, we included personal resources as independent variables with potential impact on debt literacy.

\section{Figure 1 | Distribution of Scales and Subscales}

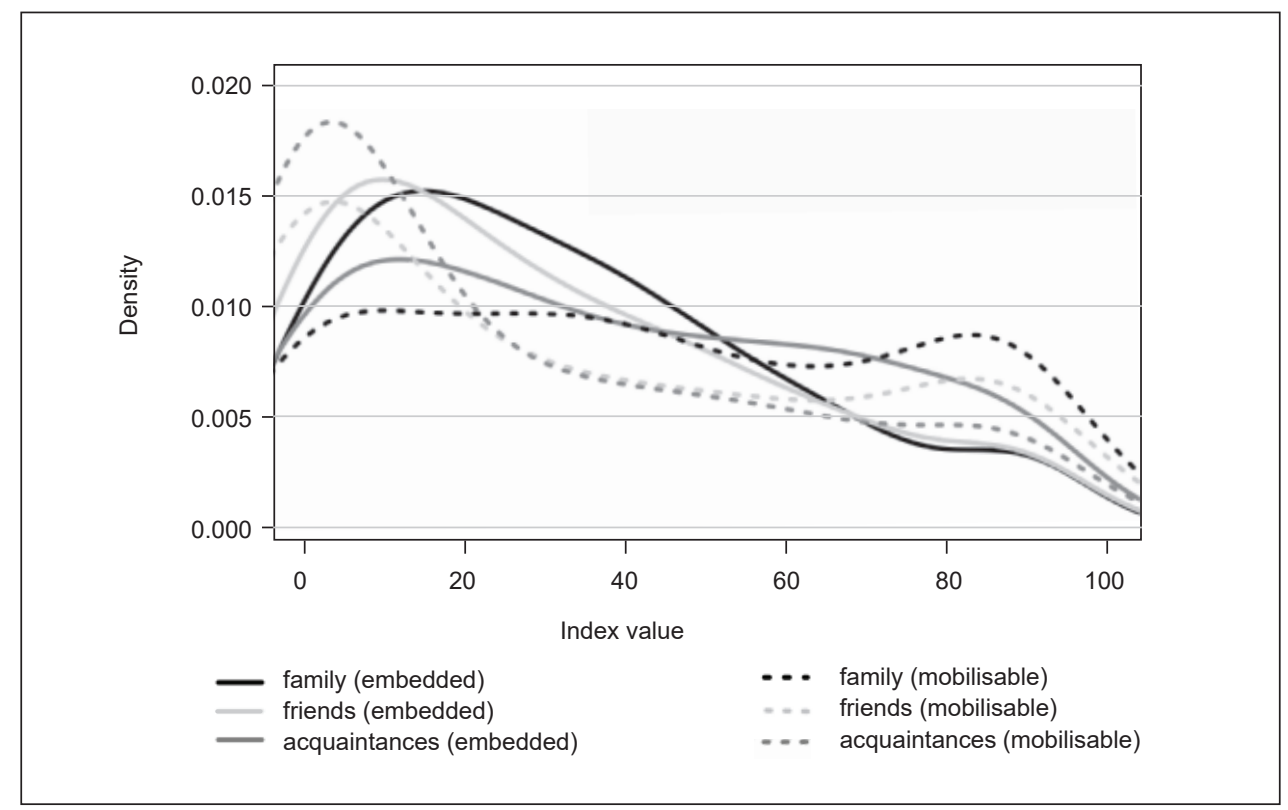

Source: Authors

2 Their test consisted of three questions (see Appendix). 
Additionally, control variables such as gender, age, place of residence and education were added to the regression models built to test the relationship between independent and dependent variables.

\section{Results and Discussion}

\subsection{Descriptive statistics}

Respondents declared their use of Facebook primarily for social and relational reasons. Nearly $83 \%$ of them plan to keep in touch with friends, while $62 \%$ aim to renew old contacts. Almost 55\% of our users treat Facebook as an important source of information and 35\% of them want to share information with others. Respectively, 23\% search for knowledge, while for $16 \%$, Facebook appears to be a chance to share knowledge with other users. Among other reasons for Facebook use, entertainment remains important for less than half $(42 \%)$ of our sample (see Figure 2$)$.

\section{Figure 2 | Reasons for using Facebook}

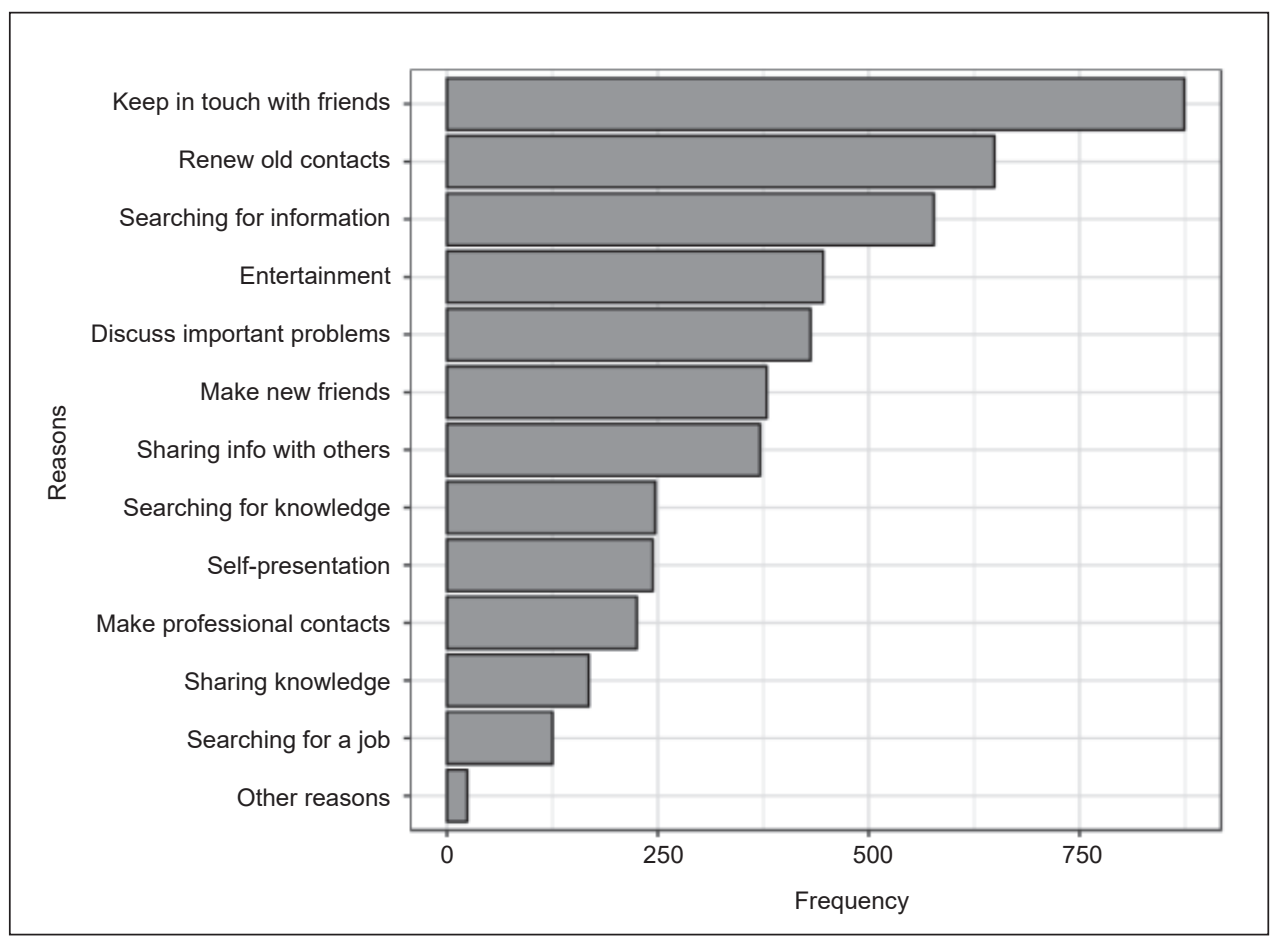

Source: Authors

In order to examine factors associated with social capital of social media users, the relational dimension of Facebook was examined with the modified version of the Facebook Relationship Maintenance Behaviour Scale proposed by Ellison et al. 
(2014). Items from this scale helped us to identify: (i) the respondent's reactions to practices of kin, friends, acquaintances and strangers on social media, (ii) reactions of others (kin, friends, acquaintances and strangers) on the respondent's social practices on social media. Although, strong ties appear to be the most important source of stimulus and help (we react and they react), many respondents point to strangers when they recall different relational practices on Facebook (see Figure 3). In other words, strangers are considered an important source of resources that may contribute to the debt literacy of Facebook users.

\section{Figure 3 | Practices on Facebook}

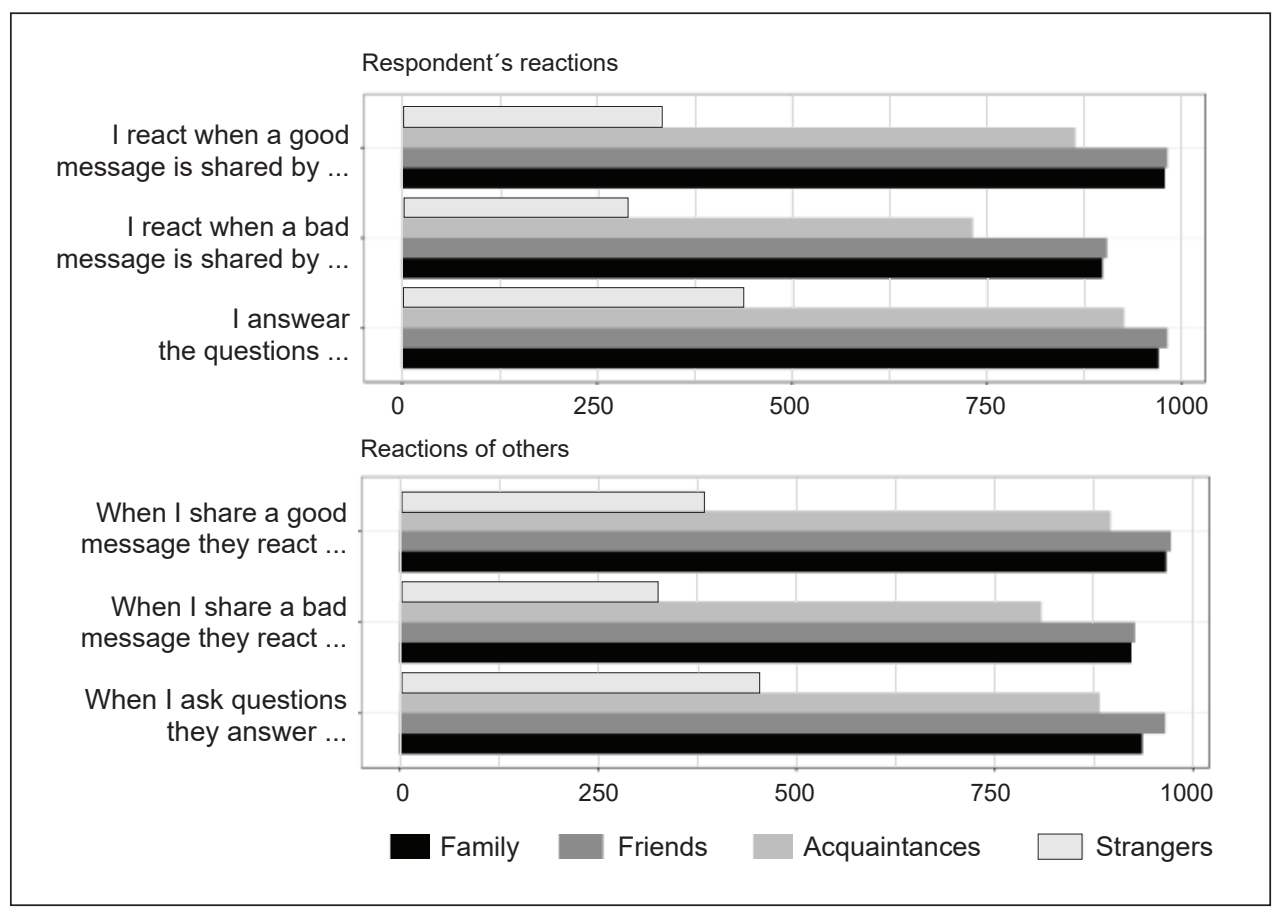

Source: Authors

\subsection{Regression results and hypothesis testing}

Our hypotheses are tested with a series of OLS regression models aimed to estimate the impact of different factors on debt literacy. Table 2 consists of all models made of the variables described above. Model 1 is based only on control variables. In Model 2, we append variables representing embedded, mobilisable and personal resources diagnosed with the Resource Generator items. Additionally, in Model 3, we focus on resources embedded and mobilisable through relations with family, friends and acquaintances. Variables measuring embedded, mobilisable and personal resources from Model 2 are therefore replaced with subscales capturing the amount of resources present in all the social circles mentioned above. All the regression models in Table 2 are nested in each other 
and estimate the relationship between the set of independent variables and the dependent variable set as an index from three questions measuring debt literacy.

In Hypothesis 1, we tested the impact of resources on debt literacy (index) of Facebook users in Poland. The results in Model 2 are quite ambiguous and are further explained in the Discussion section. The embedded resources have positive and significant $(p<0.05)$ impact on the debt literacy index, while mobilisable resources negatively influence the dependent variable but this effect is insignificant $(p>0.05)$. Thus, the impact of resources (social capital) on debt literacy is partly confirmed.

Table 2 | Regression models (OLS)

\begin{tabular}{|c|c|c|c|c|c|c|c|c|c|}
\hline & \multicolumn{3}{|c|}{ Model 1} & \multicolumn{3}{|c|}{ Model 2} & \multicolumn{3}{|c|}{ Model 3} \\
\hline & $\begin{array}{l}\text { Esti- } \\
\text { mate }\end{array}$ & $\begin{array}{l}\text { Std. } \\
\text { Error }\end{array}$ & $\operatorname{Pr}(>|t|)$ & $\begin{array}{l}\text { Esti- } \\
\text { mate }\end{array}$ & $\begin{array}{l}\text { Std. } \\
\text { Error }\end{array}$ & $\operatorname{Pr}(>|t|)$ & $\begin{array}{l}\text { Esti- } \\
\text { mate }\end{array}$ & $\begin{array}{l}\text { Std. } \\
\text { Error }\end{array}$ & $\operatorname{Pr}(>|t|)$ \\
\hline (Intercept) & 0.138 & 0.117 & 0.237 & 0.102 & 0.120 & 0.395 & 0.063 & 0.123 & 0.607 \\
\hline Gender & 0.253 & 0.048 & $0.000 * * *$ & 0.236 & 0.048 & $0.000 * * *$ & 0.237 & 0.048 & $0.000 * * *$ \\
\hline Age & 0.002 & 0.002 & 0.375 & 0.002 & 0.002 & 0.295 & 0.002 & 0.002 & 0.261 \\
\hline Place & 0.018 & 0.010 & 0.925 & 0.018 & 0.010 & 0.092 & 0.018 & 0.010 & 0.078 \\
\hline Education & 0.043 & 0.011 & $0.000 * * *$ & 0.037 & 0.011 & $0.001 * *$ & 0.036 & 0.011 & $0.000 * * *$ \\
\hline $\begin{array}{l}\text { Embedded } \\
\text { resources }\end{array}$ & - & - & - & 0.003 & 0.001 & 0.040 * & - & - & - \\
\hline $\begin{array}{l}\text { Mobilisable } \\
\text { resources }\end{array}$ & - & - & - & -0.001 & 0.001 & 0.228 & - & - & - \\
\hline $\begin{array}{l}\text { Personal } \\
\text { resources }\end{array}$ & - & - & - & 0.019 & 0.016 & 0.219 & 0.023 & 0.016 & 0.152 \\
\hline $\begin{array}{l}\text { Embedded } \\
\text { resources (family) }\end{array}$ & - & - & - & - & - & - & -0.004 & 0.015 & 0.798 \\
\hline $\begin{array}{l}\text { Embedded } \\
\text { resources (friends) }\end{array}$ & - & - & - & - & - & - & 0.007 & 0.017 & 0.684 \\
\hline $\begin{array}{l}\text { Embedded } \\
\text { resources } \\
\text { (acquaintances) }\end{array}$ & - & - & - & - & - & - & 0.026 & 0.012 & $0.036 *$ \\
\hline $\begin{array}{l}\text { Mobilisable } \\
\text { resources (family) }\end{array}$ & - & - & - & - & - & - & 0.011 & 0.012 & 0.352 \\
\hline $\begin{array}{l}\text { Mobilisable } \\
\text { resources (friends) }\end{array}$ & - & - & - & - & - & - & -0.013 & 0.014 & 0.327 \\
\hline $\begin{array}{l}\text { Mobilisable } \\
\text { resources } \\
\text { (acquaintances) }\end{array}$ & - & - & - & - & - & - & -0.012 & 0.012 & 0.332 \\
\hline R-squared & \multicolumn{3}{|c|}{0.048} & \multicolumn{3}{|c|}{0.056} & \multicolumn{3}{|c|}{0.059} \\
\hline Adj. R-squared & \multicolumn{3}{|c|}{0.044} & \multicolumn{3}{|c|}{0.050} & \multicolumn{3}{|c|}{0.049} \\
\hline
\end{tabular}

Note: Significance Codes: ${ }^{* *}=0.001 ;{ }^{* *}=0.01 ;{ }^{*}=0.05$.

Source: Authors 
Model 3 was built with resources split into different types of relations to test Hypothesis 2. In accordance with previous research (e.g., Granovetter, 1974; Lin and Dumin, 1986), our results confirmed that weak ties may be a source of valuable resources. Again, the impact of embedded resources is positive and significant $(p<0.05)$. Mobilisable resources do not influence the dependent variable significantly $(p>0.05)$.

Hypothesis 3 was tested in Model 3 (Table 2). Surprisingly, mobilisable resources have no significant impact $(p>0.05)$ on debt literacy of Facebook users in Poland. The results are further explained in the Discussion section. Those variables do not significantly affect the dependent variable - the debt literacy index. Moreover, our OLS nested models suggest that male and better-educated Facebook users in Poland achieve better scores in debt literacy tests.

\subsection{Discussion}

This study uses an online questionnaire (with the Resource Generator tool as its core) to examine the impact of social capital and individual attitudes on the debt literacy of Facebook users in Poland. Some implications of this research related to debt literacy (or financial literacy) may help to understand mechanisms behind self-learning and information distribution of credit holders. We discuss them in this section with reference to results and findings from social science literature.

As was suggested above, resources embedded in personal networks influence debt literacy (index and single questions) of Facebook users in Poland. Such findings are rather consistent with prior research based on the Resource Generator tool (Batorski et al., 2015; Webber et al., 2011). However, our research evaluates a specific dependent variable derived from Lusardi and Tufano's (2009) debt literacy test. As we expected in Hypothesis 1, users with a higher level of resources present in their personal networks are more debt-literate. The impact of social capital on the dependent variable is significant but quite complex at the same time. Only resources that cannot be mobilised for purposive action (Lin, 2001) are valid when the total score from the debt literacy test is evaluated. Mobilisable resources have a negative influence on the total score, but remain insignificant. Thus, based on regression models presented in this study, it is becoming more evident that the distinction between embedded and mobilisable resources matters when debt literacy is evaluated. Different explanations of these results are probable here, but we propose that confidence of mobilisation of resources may discourage users from self-learning or other ways of increasing their debt literacy. In other words, users aware of resources that are embedded in their personal networks, but cannot be mobilised when they are in need, may be more pressured to become debt-literate than those relying on mobilisable resources (e.g., knowledge or information) supplied by others. Self-reliance should not be surprising in a society with one of the lowest rates of generalised trust among citizens in Europe (Czapiński, 2015). In a changing society where distrust remains a "cultural rule" (Sztompka, 2000), others may not be perceived as a reliable source of help and support.

Such results, on the other hand, appear to be rational as users do not waste resources (e.g., time or money) for self-learning of skills assessed as little useful. Accordingly, 
individuals with low debt literacy scores may be proficient in other areas, e.g., gardening, foreign languages or computer programming. As Durkheim (1933) explained, members of modern societies count on others - family, friends, acquaintances or complete strangers - to secure the resources needed to achieve individual goals and objectives. In the age of digital communication, access to valued resources through social connections have become simple with Facebook, Twitter or Instagram. So, even if the specialization may cause some undesired costs, especially in highly complex and unpredicted environments, it is rather impossible to be an expert in every field of life. Thus, Hypothesis 1 is partly confirmed, as only a certain type of social capital helps people to become more debtliterate.

As expected, acquaintances (weak ties) may deliver resources that have an impact on the debt literacy of Facebook users. Although, Granovetter's (1973) "strength-of-weakties" hypothesis was confirmed in earlier research focused on a range of social problems (Ellison et al., 2007; Montgomery, 1992; Yakubovich et al., 2005), our study brings evidence that weak ties may be a source of diverse resources, such as information and knowledge for credit holders, as well. Thus, Hypothesis 2 was confirmed in Model 3 with debt literacy score examined as a dependent variable. Again, embedded resources available through acquaintance ties have a positive impact on the debt literacy of Facebook users in Poland, while the impact of acquaintances' mobilisable resources remains insignificant. However, it needs to be emphasised that social media platforms offer their users various affordances that enable access to a range of material and non-material resources supplied by acquaintances. Considering our debt literacy of social media users, the unique online infrastructure appears to be an important factor that enhances distribution of information and knowledge through weak ties.

Finally, there is no significant impact of mobilisable resources on the debt literacy score. Only users with better access to embedded resources that cannot be mobilised for purposive actions perform better in the debt literacy test. Perhaps such results are further related to Polish culture, which is characterised by individualism and a low level of generalised trust mentioned above. However, it is clear that Hypothesis 3 cannot be supported by our results.

All estimated models showed significant and positive relationships between debt literacy and two control variables - gender and education. This is consistent with findings of previous studies, conducted both in Poland (see, e.g., Cwynar et al., 2018) and in other countries (see Stolper and Walter, 2017, for a comprehensive overview). There are several hypotheses explaining the gender gap (i.e., males being more financially literate than females) that have been tested - with mixed results - in recent years (Brown and Graf, 2013; Hsu, 2014; Boggio et al., 2015). Some studies show, however, that the gap may be illusory, at least to a degree, as women tend to select the 'Don't know' option more often than men, ending up with worse financial literacy scores, because this option is routinely counted as indicating lack of knowledge. Men, instead, seem to gamble more frequently than women, and make an informed guess (Chen and Garand, 2018). Moreover, it was also found that women are less financially 
confident than men - they may know less than men, but they know more than they think they know (Lusardi and Mitchell, 2014). On the other hand, the strong link between educational attainment and debt literacy has its roots in cognitive abilities, at least to some extent. Nevertheless, the isolated effect of education on financial literacy has also been documented (Lusardi et al., 2010). Possible explanations of the effect are discussed, for instance, in Cwynar et al. (2018).

\subsection{Limitations and future research}

This study does have important limitations that need to be briefly discussed here. First, the sample used in this research was not random, so the results cannot be projected to the entire population of social media users in Poland (or elsewhere). It rather indicates complex and prospective relations between variables that could be used in future projects focused on debt literacy. It is, however, worth mentioning that probability sampling is not always the best way to collect such data (Rivers, 2006), while non-random methods may outperform random sampling in terms of estimates (Rivers, 2007).

Second, only users of one social networking site - Facebook - were examined. Facebook users in Poland are different from the general population of Poles. However, populations of this site are less skewed and inaccurate than other social network sites popular in Poland. Perhaps, future research should be based on wider samples with representatives of different social networking sites (e.g., Twitter or Instagram) or other social media platforms. Such cross-platform research could bring broader and more robust results with an opportunity to generalize from findings.

Third, the identification of resources for the Resources Generator may be different depending on cultural and local circumstances shaping financial behaviours. The set of resources proposed in this project appeared to be useful but cannot be regarded as the ultimate one. More details on how to select resources for the Resource Generator tool are framed by the production function theory (Ormel, 2002; Ormel et al., 1997). Future research could be based on the Resource Generator built around longer lists of resources relevant to debt literacy.

\section{Conclusions}

This article examines how resources constituting social capital influence debt literacy of Facebook users in Poland. It has been established that resources embedded in personal networks that cannot be mobilised for purposive actions have positive impact on the debt literacy score. In turn, the confidence of mobilisation of resources may have a negative influence on self-learning and debt literacy. Diverse effects of embedded and mobilizable resources seem to be crucial in explaining debt literacy and other socio-economic problems. We make a further contribution by showing that only weak ties (relations with acquaintances) enable access to resources having positive impact on the debt literacy score. Strong ties with family and friends remain insignificant. Thus, these results emphasize that social media have the potential to enhance and activate 
weak ties enabling access to diverse material and non-material resources. Finally, our findings confirm the existence of the gender gap in debt literacy. Men perform better than women in the debt literacy tests, which has been reported in previous works.

\section{Appendix}

The Resource Generator Questionnaire

\begin{tabular}{|c|c|c|c|c|}
\hline 1. Embedded resources & & & & \\
\hline $\begin{array}{l}\text { Does/is anyone in your Family, Friends } \\
\text { or Acquaintances ...? } \\
\text { And yourself ...? }\end{array}$ & Family & Friends & $\begin{array}{c}\text { Acquain- } \\
\text { tances }\end{array}$ & $\begin{array}{l}\text { Respondent } \\
\text { (personal) }\end{array}$ \\
\hline earn more than $6 \mathrm{~K}$ PLN per month & Yes / No & Yes / No & Yes / No & Yes / No \\
\hline have a house in a holiday resort & Yes / No & Yes / No & Yes / No & Yes / No \\
\hline run a profitable business & Yes / No & Yes / No & Yes / No & Yes / No \\
\hline work in a bank or financial institution & Yes / No & Yes / No & Yes / No & Yes / No \\
\hline familiar with finance & Yes / No & Yes / No & Yes / No & Yes / No \\
\hline benefit from various credits & Yes / No & Yes / No & Yes / No & Yes / No \\
\hline have a vast knowledge of economics & Yes / No & Yes / No & Yes / No & Yes / No \\
\hline read economic press & Yes / No & Yes / No & Yes / No & Yes / No \\
\hline a financial adviser & Yes / No & Yes / No & Yes / No & Yes / No \\
\hline
\end{tabular}

\begin{tabular}{|c|c|c|c|}
\hline 2. Mobilisable resources & \multirow[b]{2}{*}{ Family } & \multirow[b]{2}{*}{ Friends } & \multirow[b]{2}{*}{ Acquaintances } \\
\hline $\begin{array}{l}\text { Can anyone in your Family, Friends } \\
\text { or Acquaintances ...? }\end{array}$ & & & \\
\hline borrow a few thousand PLN & Yes / No & Yes / No & Yes / No \\
\hline advise how to avoid the debt spiral & Yes / No & Yes / No & Yes / No \\
\hline share a house or flat with you & Yes / No & Yes / No & Yes / No \\
\hline put you in touch with a financial adviser & Yes / No & Yes / No & Yes / No \\
\hline recommend a good credit/loan & Yes / No & Yes / No & Yes / No \\
\hline advise on how to invest money & Yes / No & Yes / No & Yes / No \\
\hline help to appraise a credit agreement & Yes / No & Yes / No & Yes / No \\
\hline advise on how to reduce debt & Yes / No & Yes / No & Yes / No \\
\hline help to sue a bank/financial institution & Yes / No & Yes / No & Yes / No \\
\hline
\end{tabular}




\section{Lusardi and Tufano test}

Question 1: Suppose you owe $\$ 1,000$ on your credit card and the interest rate you are charged is $20 \%$ per year compounded annually. If you didn't pay anything off, at this interest rate, how many years would it take for the amount you owe to double?

Answers:

2 years,

Less than 5 years,

5 to 10 years,

More than 10 years,

Do not know,

Prefer not to answer.

Question 2: You owe $\$ 3,000$ on your credit card. You pay a minimum payment of $\$ 30$ each month. At an Annual Percentage Rate of $12 \%$ (or 1\% per month), how many years would it take to eliminate your credit card debt if you made no additional new charges?

Answers:

Less than 5 years,

Between 5 and 10 years,

Between 10 and 15 years,

Never, you will continue to be in debt,

Do not know,

Prefer not to answer.

Question 3: You purchase an appliance which costs $\$ 1,000$. To pay for this appliance, you are given the following two options: a) Pay 12 monthly instalments of $\$ 100$ each; b) Borrow at a $20 \%$ annual interest rate and pay back $\$ 1,200$ a year from now. Which is the more advantageous offer?

Answers:

Option (a),

Option (b),

They are the same,

Do not know,

Prefer not to answer.

\section{References}

Appel, L., Dadlani, P., Dwyer, M., Hampton, K., Kitzie, V., Matni, Z. A., Teodoro, R. (2014). Testing the Validity of Social Capital Measures in the Study of Information and Communication Technologies. Information, Communication \& Society, 17(4), 398-416, http://doi.org/10.108 0/1369118X.2014.884612

Ark, L. A. van der (2007). Mokken Scale Analysis in R. Journal of Statistical Software, 20(11), 1-19, https://doi.org/10.18637/jss.v020.i11 
Baborska-Narozny, M., Stirling, E., Stevenson, F. (2016). Exploring the Relationship between a "Facebook Group" and Face-to-Face Interactions in "Weak-Tie" Residential Communities. Proceedings of the 7th 2016 International Conference on Social Media \& Society - SMSociety '16 (pp. 1-8). New York, NY, USA: ACM, http://doi.org/10.1145/2930971.2930989

Bakshy, E., Rosenn, I., Marlow, C., Adamic, L. (2012). The Role of Social Networks in Information Diffusion. Proceedings of the 21st International Conference on World Wide Web (pp. 519-528). New York, NY, USA: ACM.

Batorski, D., Bojanowski, M., Filipek, K. (2015). Getting a Job: Resources and Individual's Chances on the Warsaw Labour Market. Polish Sociological Review, 192(4), 475-492.

Białowolski, P., Cwynar, A., Cwynar, W. (2019). Decomposition of the Financial Literacy Construct: A Structural Model of Debt Knowledge, Skills, Confidence, Attitudes, and Behavior. Available at: https://papers.ssrn.com/sol3/papers.cfm?abstract_id=3448937

Boggio, C., Fornero, E., Prast, H., Sanders, J. (2015). Seven Ways to Knit Your Portfolio. Is Investor Communication Neutral? Network for Studies on Pensions, Aging and Retirement. Tilburg NETSPAR Academic Series. Working Paper No. DP 10/2015-030, https://doi.org/10.2139/ ssrn.2668579

Bourdieu, P. (1986). The Forms of Capital, in Richardson, J. G., ed., Handbook of Theory of Research for the Sociology of Education. New York: Greenwood Press, pp. 46-58.

Brown, M., Graf, R. (2013). Financial Literacy, Household Investment and Household Debt. Swiss Institute of Banking and Finance, University of St. Gallen. Working Papers on Finance No. $13 / 1$.

Buckley, N. (2016). Polish Banks Spared Forced Conversion of Swiss Franc Mortgages. Financial Times. August 2, 2016. Available at: https://www.ft.com/ content/487c839c-58b7-11e6-8d05-4eaa66292c32

Callegaro, M., Villar, A., Yeager, D., Krosnick, J. A. (2014). A Critical Review of Studies Investigating the Quality of Data Obtained with Online Panels based on Probability and Nonprobability Samples, in Callegaro, M., Baker, R., Bethlehem, J., Goritz, A. S., Krosnick, J. A., Lavrakas, P. J., eds., Online Panel Research: A Data Quality Perspective. Hoboken, New Jersey, USA: John Wiley \& Sons, Ltd, pp. 23-53, https://doi.org/10.1002/9781118 763520.ch2

Chen, Z., Garand, J. C. (2018). On the Gender Gap in Financial Knowledge: Decomposing the Effects of Don't Know and Incorrect Responses'. Social Science Quarterly, 99(5), 1551-1571, https://doi.org/10.1111/ssqu. 12520

Coleman, J. S. (1988). Social Capital in the Creation of Human Capital. American Journal of Sociology, 94, 95-120, https://doi.org/10.1086/228943

Collier, P. (2002). Social Capital and Poverty: A Microeconomic Perspective, in Grootaert, C., Van Bastelaer, T., eds., The Role of Social Capital in Development. An Empirical Assessment. Cambridge: Cambridge University Press, pp. 19-41, https://doi.org/10.1017/ cbo9780511492600.003

Crossney, K. B. (2017). Who's at-risk? A Case Study of the Demographic and Socioeconomic Characteristics of Census Tracts Experiencing Predatory and Abusive Mortgage Lending in Philadelphia. Geoforum, 81, 129-143, http://doi.org/10.1016/j.geoforum.2017.02.013

Crotty, J. (2009). Structural Causes of the Global Financial Crisis: A Critical Assessment of the "New Financial Architecture". Cambridge Journal of Economics, 33(4), 563-580, http://doi.org/10.1093/cje/bep023 
Cwynar, A., Cwynar, W., Wais, K. (2018). Debt Literacy and Debt Literacy Self-Assessment: The Case of Poland. Journal of Consumer Affairs, 53(1), 24-57, https://doi.org/10.1111/ joca. 12190

Czapiński, J. (2015). State of the Civil Society: Objective and Subjective Quality of Life in Poland 2015. Contemporary Economics, 9(4), 332-372.

Daly, M., Delaney, L., Séamus, M. (2010). Risk Attitudes as an Independent Predictor of Debt. Geary Institute, University College Dublin. Dublin Geary Institute Discussion Paper Series No. 201049.

Dasgupta, P. (2005). Economics of Social Capital. Economic Record, 81(1), 2-21. https://doi. org/10.1111/j.1475-4932.2005.00245.x

De Graaf, N. D., Flap, H. D. (1988). "With a Little Help from My Friends”: Social Resources as an Explanation of Occupational Status and Income in West Germany, The Netherlands, and the United States. Social Forces, 67(2), 452-472, http://doi.org/10.1093/sf/67.2.452

Durkheim, E. (1933). The Division of Labour in Society. Translated by G. Simpson. New York: Free Press.

Durlauf, S. N. (2002). Bowling Alone: A Review Essay. Journal of Economic Behavior and Organization, 47(3), 259-273, http://doi.org/10.1016/S0167-2681(01)00210-4

Ellison, N. B., Gray, R., Lampe, C., Fiore, A. T. (2014). Social Capital and Resource Requests on Facebook. New Media \& Society, 16(7), 1104-1121, http://doi. org/10.1177/1461444814543998

Ellison, N. B., Steinfield, C., Lampe, C. (2007). The Benefits of Facebook "Friends:" Social Capital and College Students' Use of Online Social Network Sites. Journal of Computer-Mediated Communication, 12(4), 1143-1168, http://doi.org/10.1111/j.1083-6101.2007.00367.x

Ellison, N. B., Vitak, J., Gray, R., Lampe, C. (2014). Cultivating Social Resources on Social Network Sites: Facebook Relationship Maintenance Behaviors and Their Role in Social Capital Processes. Journal of Computer-Mediated Communication, 19(4), 855-870, http://doi. org/10.1111/jcc4.12078

Falk, I. (2001). Literacy by Design, not by Default: Social Capital's Role in Literacy Learning. Journal of Research in Reading, 24(3), 313-323, https://doi.org/10.1111/1467-9817.00152

FED NY. (2017). Household Debt and Credit. Center for Microeconomic Data - Quarterly Report. New York: FED. [Retrieved 2018-11-023] Available at: https://www.newyorkfed.org/ medialibrary/interactives/householdcredit/data/pdf/hhdc_2017q4.pdf

Field, J. (2005). Social Capital and Lifelong Learning. Bristol: The Policy Press, http://doi. org/10.2307/j.ctt9qgvrm

Filipek, K. (2016). Sharing Resources on Facebook Groups: Polish Emigrants in Germany, Norway and UK. Konteksty Społeczne/Social Contexts, Special Issue: Rediscovering Society in the Age of Social Media, 4(1), 42-53.

Fischer, C. S. (2005). Bowling Alone: What's the Score? Social Networks, 27(2), 155-167, http://doi.org/10.1016/j.socnet.2005.01.009

Gaag, M. van der, Snijders, T. A. B. (2005). The Resource Generator: Social Capital Quantification with Concrete Items. Social Networks, 27(1), 1-29, http://doi.org/10.1016/j. socnet.2004.10.001

Gaag, M. van der, M., Snijders, T. A. B., Flap, H. (2008). Position Generator Measures and Their Relationship to Other Social Capital Measures, in Lin, N., Erickson, B., eds., Social Capital: An International Research Program. Oxford: Oxford University Press, pp. 27-48, https://doi.org/10.1093/acprof:oso/9780199234387.003.0011 
Garðarsdóttir, R. B., Dittmar, H. (2012). The Relationship of Materialism to Debt and Financial Well-being: The Case of Iceland's Perceived Prosperity. Journal of Economic Psychology, 33, 471-481, http://doi.org/10.1016/j.joep.2011.12.008

Granovetter, M. (1973). The Strength of Weak Ties. The American Journal of Sociology, 78(6), 1360-1380, http://doi.org/10.1086/225469

Granovetter, M. (1974). Getting a Job: A Study of Contacts and Careers. Chicago and London: The University of Chicago Press. ISBN 9780226305813.

Hamidi, F., Baljko, M. (2010). Collaborative Poetry on the Facebook Social Network. Proceedings of the 16th ACM International Conference on Supporting Group Work, (pp. 305-306). Sanibel Island, Florida, USA: GROUP'10, http://doi.org/10.1145/1880071.1880122

Hays, R. A. (2015). Neighborhood Networks, Social Capital, and Political Participation: The Relationships Revisited. Journal of Urban Affairs, 37(2), 122-143, http://doi. org/10.1111/juaf.12137

Hays, R. D., Liu, H., Kapteyn, A. (2015). Use of Internet Panels to Conduct Surveys. Behavior Research Methods, 47(3), 685-690, http://doi.org/10.3758/s13428-015-0617-9

Hsu, J. W. (2016). Aging and Strategic Learning: The Impact of Spousal Incentives on Financial Literacy. Journal of Human Resources, 51(4), 1036-1067, http://doi.org/10.3368/ jhr.51.4.1014-6712R

Krackhardt, D. (1992). The Strength of Strong Ties: The Importance of Philos in Organizations, in Nohria, N., Eccles, R. G., eds., Networks and Organizations. Boston: Harvard Business School Press, pp. 216-239.

La Due Lake, R., Huckfeldt, R. (1998). Social Capital, Social Networks, and Political Participation. Political Psychology, 19(3), 567-584, https://doi.org/10.1111/0162-895x.00118

Lampe, C., Vitak, J., Gray, R., Ellison, N. (2012). Perceptions of Facebook's Value as an Information Source. Proceedings of the SIGCHI Conference on Human Factors in Computing Systems (pp. 3195-3204). Austin, Texas, USA: CHI '12, http://doi.org/10.1145/2207676.2208739

Lin, N. (1999). Building a Network Theory of Social Capital. Connections, 22(1), 28-51, http://doi.org/10.1108/14691930410550381

Lin, N. (2001). Social Capital. A Theory of Social Structure and Action. Cambridge, Malden: Cambridge University Press. ISBN 978-0521521673, http://doi.org/10.1007/ s13398-014-0173-7.2

Lin, N., Dumin, M. (1986). Access to Occupations through Social Ties. Social Networks, 8(4), 365-385, https://doi.org/10.1016/0378-8733(86)90003-1

Lin, N., Vaughn, J. C., Ensel, W. M. (1981). Social Resources and Occupational Status Attainment. Social Forces, 59(4), 1163-1181, http://doi.org/10.2307/2577987

Loury, G. C. (1977). A Dynamic Theory of Racial Income Differences, in Books, L., ed., Women, Minorities, and Employment Discrimination. Lexington, MA: Lexington Books.

Lusardi, A., Mitchell, O. S. (2014). The Economic Importance of Financial Literacy: Theory and Evidence. Journal of Economic Literature, 52(1), 5-44, http://doi.org/10.1257/jel.52.1.5

Lusardi, A., Mitchell, O. S., Curto, V. (2014). Financial Literacy among the Young. Journal of Consumer Affairs, 44(2), 350-380, https://doi.org/10.1111/j.1745-6606.2010.01173.x

Lusardi, A., Tufano, P. (2009). Debt Literacy, Financial Experiences and Overindebtedness. National Bureau of Economic Research. NBER Working Paper Series No. 14808, https://doi. org/10.3386/w14808 
Martinsson, J., Dahlberg, S., Lundmark, S. O. (2013). Is Accuracy Only for Probability Samples? Comparing Probability and Non-probability Samples in a Country with Almost Full Internet Coverage. 68th Annual Conference of the American Association for Public Opinion Research (AAPOR), Boston, Massachusetts. [Retrieved 2018-10-07] Available at: https:// lore.gu.se/digitalAssets/1455/1455221_martinsson--dahlberg-and-lundmark--2013-aapor-is-accuracy-only-for-probability-samples.pdf

Mazer, J. P., Murphy, R. E., Simonds, C. J. (2007). I'Il See You on "Facebook": The Effects of Computer-mediated Teacher Self-disclosure on Student Motivation, Affective Learning, and Classroom Climate. Communication Education, 56(1), 1-17. http://doi.org/10.1080/03634520601009710

Megapanel PBI/Gemius (2015). [Retrieved 2018-11-27] Available at: https://www.gemius.pl/ files/PL/infografika_17_02/2015_10_FacebookTwitter.png

Montgomery, J. D. (1992). Job Search and Network Composition: Implications of the Strengthof-weak-ties Hypothesis. American Sociological Review, 57(5), 586-596, https://doi. org/10.2307/2095914

Norvilitis, J. M., Merwin, M. M., Osberg, T. M., Roehling, P. V., Young, P., Kamas, M. M. (2006). Personality Factors, Money Attitudes, Financial Knowledge, and Credit-card Debt in College Students. Journal of Applied Social Psychology, 36(6), 1395-1413, https://doi.org/10.1111/j.0021-9029.2006.00065.x

Open Science Collaboration. (2015). Estimating the Reproducibility of Psychological Science. Science, 349(6251), 943-951, http://doi.org/10.1126/science.aac4716

Ormel, J., Lindenberg, S., Steverink, N., Vonkorff, M. (1997). Quality of Life and Social Production Functions: A Framework for Understanding Health Effects. Social Science \& Medicine, 45(7), 1051-63, http://doi.org/10.1016/S0277-9536(97)00032-4

Ostrom, E. (1995). Self-organization and Social Capital. Industrial and Corporate Change, 4(1), 131-159, https://doi.org/10.1093/icc/4.1.131

Patton, D., Kenney, M. (2003). Innovation and Social Capital in Silicon Valley. Berkeley Roundtable on the International Economy. Working Paper No. 155. Available at: http://www.efortrade.com/project_eseune/archivos_hitos/2350/Regions\%20and\%20Innovation\%20 Silicon\%20Valley.pdf

Paxton, P. (1999). Is Social Capital Declining in the United States? A Multiple Indicator Assessment. American Journal of Sociology, 105(1), 88-127, http://doi.org/10.1086/210268

PEW Research Center (2015). The Evolving Role of News on Twitter and Facebook. Pew Research Center. Available at: http://www.journalism.org/files/2015/07/Twitter-and-News-SurveyReport-FINAL2.pdf

Putnam, R. D. (1995). Bowling Alone: America's Declining Social Capital. Journal of Democracy, 6(1), 65-78, http://doi.org/10.1016/S0362-3319(02)00190-8

Putnam, R. D. (2000). Bowling Alone: The Collapse and Revival of American Community. New York, London, Toronto, Sydney, Singapore: Simon \& Schuster. http://doi.org/10.1007/ s13398-014-0173-7.2

R Core Team (2017). R: A Language and Environment for Statistical Computing. R Foundation for Statistical Computing, Vienna, Austria. 2016.

Rivers, D. (2006). Sample Matching: Representative Sampling from Internet Panels. Polimetrix White Paper Series. [Retrieved 2018-11-07] Available at: http://www.websm.org/uploadi/ editor/1368187057Rivers_2006_Sample_matching_Representative_sampling_from_ Internet_panels.pdf 
Rivers, D. (2007). Sampling for Web Surveys. Joint Statistical Meetings. [Retrieved 2018-11-07] Available at: https://pdfs.semanticscholar.org/fffa/a7e52c5d163a0944974a68160ee6e0 a6b481.pdf

Rogosic, S., Baranovic, B. (2016). Social Capital and Educational Achievements: Coleman vs. Bourdieu. CEPS Journal, 6(2), 81-100.

Skocpol, T. (1996). Unravelling from Above. The American Prospect, 25(7), 20-24.

Statistics Poland (2018). Demographic Yearbook of Poland. Warsaw: Central Statistical Office.

Steffes, E. M., Burgee, L. E. (2009). Social Ties and Online Word of Mouth. Internet Research, 19(1), 42-59, http://doi.org/10.1108/10662240910927812

Stolper, O. A., Walter, A. (2017). Financial Literacy, Financial Advice, and Financial Behavior. Journal of Business Economics, 87(5), 581-643, https://doi.org/10.1007/s11573-017-0853-9

Sztompka, P. (2000). Trust: A Sociological Theory. Cambridge, New York, Port Melbourne: Cambridge University Press.

Tett, L., Maclachlan, K. (2007). Adult Literacy and Numeracy, Social Capital, Learner Identities and Self-confidence. Studies in the Education of Adults, 39(2), 150-167, http://doi.org/10.10 80/02660830.2007.11661546

Valenzuela, S., Correa, T., Gil de Zúñiga, H. (2018). Ties, Likes, and Tweets: Using Strong and Weak Ties to Explain Differences in Protest Participation across Facebook and Twitter Use. Political Communication, 35(1), 1-18, http://doi.org/10.1080/10584609.2017.1334726

Watson, J. J. (2003). The Relationship of Materialism to Spending Tendencies, Saving, and Debt. Journal of Economic Psychology, 24, 723-739, http://doi.org/10.1016/j.joep.2003.06.001

Webber, M., Huxley, P., Harris, T. (2011). Social Capital and the Course of Depression: Six-month Prospective Cohort Study. Journal of Affective Disorders, 129(1-3), 149-157, http://doi. org/10.1016/j.jad.2010.08.005

Wellman, B., Haase, A. Q., Witte, J., Hampton, K. (2001). Does the Internet Increase, Decrease, or Supplement Social Capital? American Behavioral Scientist, 45(3), 436-455, https://doi. org/10.1177/00027640121957286

Wells, T., Link, M. (2014). Facebook User Research Using a Probability-based Sample and Behavioral Data. Journal of Computer-Mediated Communication, 19(4), 1042-1052, https://doi.org/10.1111/jcc4.12058

Yakubovich, V., Earle, J., Miller, S. (2005). Weak Ties, Information, and Influence: How Workers Find Jobs in a Local Russian Labor Market. American Sociological Review, 70(3), 408-421, https://doi.org/10.1177/000312240507000303

Yeager, D. S., Krosnick, J. A., Chang, L., Javitz, H. S., Levendusky, M. S., Simpser, A., Wang, R. (2011). Comparing the Accuracy of RDD Telephone Surveys and Internet Surveys Conducted with Probability and Non-probability Samples. Public Opinion Quarterly, 75(4), 709-747, http://doi.org/10.1093/poq/nfr020 